\title{
OPTIMALISASI KINERJA AIRCONDITIONER WATER HEATER (AWH) DENGAN MENGATUR DIMENSI KOIL PEMANAS AIR
}

\author{
Ika Yuliyani \\ Jurusan Teknik Konversi Energi - Politeknik Negeri Bandung \\ E-mail: i.yuliyani@gmail.com
}

\begin{abstract}
Abstrak
Airconditioner Water Heater (AWH) adalah upaya pemanfaatan panas pada kondensor mesin AC dengan tidak mengurangi fungsi AC sebagai pendingin ruangan. Prinsip kerja dari sistem ini mengunakan siklus refrigerasi kompresi uap, yaitu pada sisi evaporator digunakan untuk mendinginkan ruangan sedangkan pada sisi antara kompresor dan kondensor dimanfaatkan untuk proses pemanasan. Salah satu parameter dari kinerja Airconditioner Water Heater (AWH) adalah menghasilkan waktu pemanasan air yang relatif singkat, yaitu kurang dari 3 jam dengan penurunan tekanan $(\triangle P)$ berada pada daerahyang aman atau dibawah $34 \mathrm{kPa}$. Optimalisasi kinerja sistem AWH dilakukan dengan mengatur dimensi pipa pemanas air yaitu panjang $(L)$ dan diameter $(D)$ pipa. Sebelum dilakukan optimalisasi sistem AWH dengan panjang pipa pemanas air 15 meter menghasilkan waktu pemanasan 2 jam 10 menit dengan $\triangle P$ sebesar $36 \mathrm{kPa}$. Hasil optimalisasi dengan metode perhitungan perpindahan panas diperoleh $L=13,57$ menghasilkan waktu pemanasan air sebesar 2 jam 45 menit dan penurunan tekanan sebesar 24 $k P a$.
\end{abstract}

Kata kunci: Airconditioner Water Heater, kondensor, panjang pipa, pemanas air

\section{PENDAHULUAN}

\section{Latar Belakang}

Indonesia adalah salah satu negara yang beriklim tropis dengan temperatur udara yang cukup panas dan tingkat kelembaban tinggi. Menurut data dari badan meteorologi dan geofisika, Indonesia memiliki kondisi temperatur udara antara $23-36^{\circ} \mathrm{C}$ dengan kelembaban atau relative humidity $(\mathrm{RH})$ antara $51-98 \%$. Untuk mendapatkan kenyamanan, kesehatan dan kesegaran udara dalam rumah atau bangunan-bangunan bertingkat, maka diperlukan suatu cara yang salah satunya dengan menggunakan mesin pengkondisian udara atau Air Conditioner (AC).

Selain dibutuhkan kondisi udara yang segar, terutama di beberapa tempat seperti hotel, apartemen dan perumahan di kota-kota besar juga dibutuhkan adanya fasilitas air panas untuk keperluan mandi. Oleh karena itu, hal ini dapat mendorong tempat-tempat tersebut untuk menyediakan mesin pengkondisian udara dan alat pemanas air. Tentu saja ini akan memperbesar dana atau biaya yang harus dikeluarkan. Usaha akan pemenuhan terhadap kebutuhan tersebut dan upaya untuk penghematan membuat beberapa peneliti mencari cara bagaimana menyediakan suatu alat/mesin alternatif yang mempunyai fungsi ganda sebagai pendingin ruangan dan pemanas air atau dikenal dengan istilah Airconditioner Water Heater (AWH).

Airconditioner Water Heater (AWH) adalah upaya memanfaatkan panas pada kondensor dari mesin $\mathrm{AC}$ dengan tidak mengurangi fungsi $\mathrm{AC}$ sebagai pendingin ruangan. Prinsip kerja dari sistem ini mengunakan siklus refrigerasi kompresi uap, yaitu pada sisi evaporator digunakan untuk mendinginkan ruangan dan pada sisi antara kompresor dan kondensor dimanfaatkan untuk memanaskan. Pada sistem ini alat yang ditambahkan adalah pemanas air yang terpasang diantara kompresor dan kondensor.

Tujuan dan Manfaat

Melalui penelitian ini dapat dipelajari tentang bagaimana menentukan dimensi (panjang dan diameter) efektif dari koil pemanas air sebagai alat penukar panas yang terpasang pada sistem Airconditioner Water Heater. Dengan dimensi koil yang efektif ini diharapkan dapat lebih mengoptimumkan kerja dari alat pemanas dan kinerja dari mesin $\mathrm{AC}$ sesuai dengan tipe dan kapasitas dari mesin AC yang akan digunakan.

\section{TINJAUAN PUSTAKA}

Prinsif Kerja Airconditioner Water Heater Airconditioner Water Heater adalah pemanas air yang memanfaatkan temperatur refrigeran yang sangat tinggi pada saat keluar dari kompresor. Pada sistem pengkondisi udara khususnya tipe split, 
temperatur tersebut biasanya akan diturunkan (dibuang) pada kondensor melalui mekanisme perpindahan panas antara fluida refrigeran dengan udara yang dilewatkan oleh kipas. Tetapi pada airconditioner water heater sebelum masuk kondensor, aliran refrigeran panas tersebut dibelokkan ke dalam tangki yang berisi air dingin. Di dalam tangki terdapat koil yang disebut dengan penukar panas, sehingga terjadi kontak antara refrigeran panas dan air dingin pada tangki tersebut. Air yang semula dingin perlahan akan memanas sesuai dengan temperatur yang diinginkan. Sebaliknya refrigeran yang semula sangat panas temperaturnya akan menurun.

Pada Gambar 1 ditunjukkan bahwa refrigeran yang masuk melalui evaporator (4) berbentuk cair (ditunjukkan oleh warna biru) dan temperaturnya sangat dingin, kemudian alirkan ke dalam ruangan sehingga ruangan menjadi dingin, sementara panas yang ada di ruangan tadi diserap oleh refrigeran sehingga refrigeran yang keluar dari evaporator (1) berangsurangsur menjadi hangat (ditunjukkan oleh warna kuning), yang selanjutnya masuk ke kompresor. Setelah melalui kompresor refrigeran dikompresikan (2) sehingga temperatur refrigeran menjadi lebih panas (ditunjukkan oleh warnah merah) dan berbentuk gas dengan temperatur antara $80^{\circ} \mathrm{C}$ sampai $100^{\circ} \mathrm{C}$. Refrigeran panas (2) tersebut lalu disalurkan ke dalam tangki water heater di mana sebelumnya tangki sudah terisi oleh air dingin (air baku). Dengan demikian pertukaran energi panas terjadi antara refrigeran dengan air dingin melalui alat penukar panas berupa koil yang tersedia pada tangki. Air yang semula dingin perlahan akan memanas menuju temperatur refrigerannya, sebaliknya temperatur refrigeran akan mengalami penurunan temperatur. Pada titik 3a refrigeran yang temperaturnya mengalami penurunan (ditunjukkan oleh warna kuning) setelah keluar dari tangki, selanjutnya diturunkan kembali oleh kondensor dengan udara yang ditiup oleh fan dan refrigeran tersebut dialirkan kembali ke evaporator.

\section{Perpindahan Panas}

Perpindahan panas adalah proses perpindahan energi termal yang diakibatkan oleh perbedaan temperatur. Perpindahan panas yang terjadi pada alat pemanas air yang dirancang adalah perpindahan panas konveksi bebas, konduksi, dan konveksi paksa internal (Internal Forced Convection). Pada perpindahan panas dikenal bilangan Nusselt yaitu perbandingan perpindahan panas konveksi dan dan konduksi.

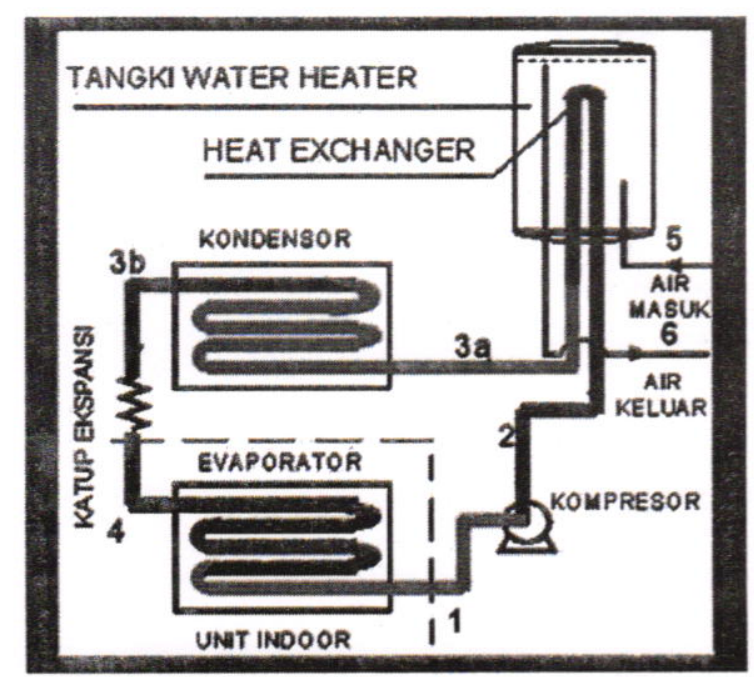

Gambar 1. KerjaAirconditioner Water Heater

$$
N u=\frac{n_{x} D}{k} \text {; }
$$

Bilangan Nusselt digunakan untuk mendapatkan koefisien konveksi yang kemudian digunakan untuk mendapatkan besar perpindahan panas

$$
Q=h_{x} \pi D\left(T_{s}-T_{\infty}\right) L_{j}
$$

Perpindahan Panas Konveksi Bebas

Konveksi bebas terjadi apabila tidak ada gerakan fluida yang disebabkan oleh pompa, fan, atau kompresor. Pada keadaan ini gerakan fluida terjadi karena terdapat gradien temperatur. Gradien temperatur menyebabkan perbedaan massa jenis fluida sehingga dengan adanya gravitasi bumi menyebabkan pergerakan fluida. Pada konveksi bebas dikenal beberapa besaran tak berdimensi berikut:

$$
\begin{gathered}
G r_{L}=\frac{g \beta\left(T_{s}-T_{m a}\right)}{v^{2}} \ldots \ldots \ldots \ldots(3) \\
R a_{L}=G r_{L} P r=\frac{g \beta\left(T_{s}-T_{\infty}\right) D^{3}}{v \alpha} \ldots \ldots
\end{gathered}
$$

Korelasi empirik untuk bilangan Nussel untuk silinder horisontal panjang telah diusulkan oleh Churchill dan Chu, yaitu:

$\overline{N u_{L}}=\left\{0.6+\frac{0.387 R a_{L}{ }^{2 / 6}}{\left[1+\left(0.559 / \mathrm{Pr}^{2}\right)^{3 / 16}\right]^{\frac{3}{27}}}\right\}^{2} ; \quad R a_{D} \leq 10^{12}$ 
Perpindahan Panas Konveksi Paksa Internal Konveksi paksa di dalam pipa sangat dipengaruhi oleh keadaan aliran di dalam pipa, selanjutnya perlu diketahui terlebih dahulu apakah aliran berada di daerah dalam entry region atau fully developed, keadaan aliran laminar atau turbulen, atau dalam keadaan berubah fasa (penguapan dan pengembunan). Untuk menentukan aliran laminar atau turbulen dapat diperkirakan dari besar bilangan Reynolds, melalui persamaan sebagai berikut:

$$
R e_{D}=\frac{4 \dot{m}}{\pi D \mu}
$$

\section{Perpindahan Panas Konveksi Paksa Dalam Pipa pada Aliran Turbulen}

Korelasi perpindahan panas konveksi paksa di dalam pipa pada aliran turbulen biasanya didapatkan dari hubungan empirik. Salah satu persamaan yang dapat digunakan adalah persamaan yang diusulkan oleh DittuS-Boelter, yaitu:

$$
N u_{D}=0.023 R e_{D} \frac{\stackrel{4}{5}}{P} r^{n} .
$$

\section{Perbedaan Tekanan dan Faktor Gesekan di dalam Pipa}

Pada saat fluida mengalir di dalam pipa selalu ada gesekan yang terjadi sehingga menimbulkan perubahan tekanan. Dalam menentukan perubahan tekanan pada pipa yang terjadi, dapat digunakan diagram Moody.

$$
\Delta P=f \frac{\rho u^{2} L}{2 D_{i}} .
$$

\section{METODOLOGI}

Metode yang digunakan pada penelitian ini adalah sebagai berikut:

1. Studi literatur

2. Menentukan dimensi pipa dengan melakukan perhitungan secara teoritis. Effektivitas dari pipa pemanas air dipeloleh dari metode perhitungan perpindahan panas dengan menggunakan asumsi bahwa pipa pemanas berbentuk konus heliks. Adapun tahapan perhitungannya adalah sebagai berikut:

a. Mengetahui atau menentukan spesifikasi dari mesin AC yang digunakan.

b. Menghitung potensi energi panas pada mesin AC dari data spesifikasi alat. c. Menghitung dimensi yaitu panjang pipa (L) dan perkiraan pressure drop yang terjadi pada pipa pemanas air.

3. Desain dan pembuatan pipa pemanas air.

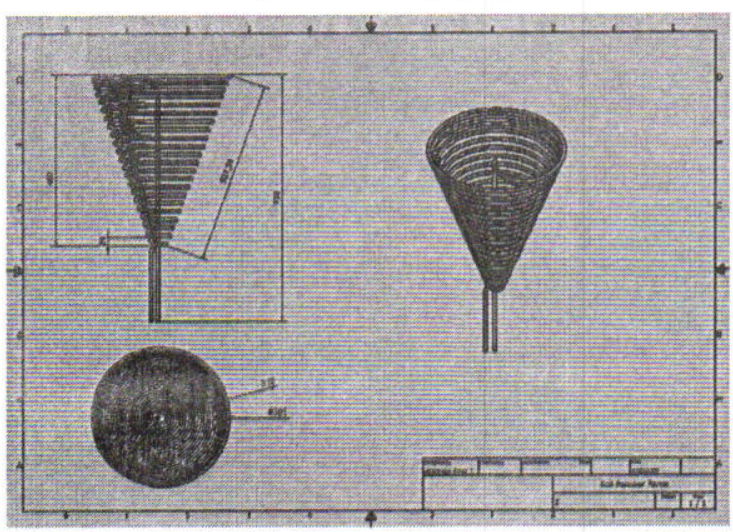

Gambar 2.Disain pipa konus

4. Instalasi Alat yang berada didalam tangki air dengan pipa kondensor dari mesin AC.

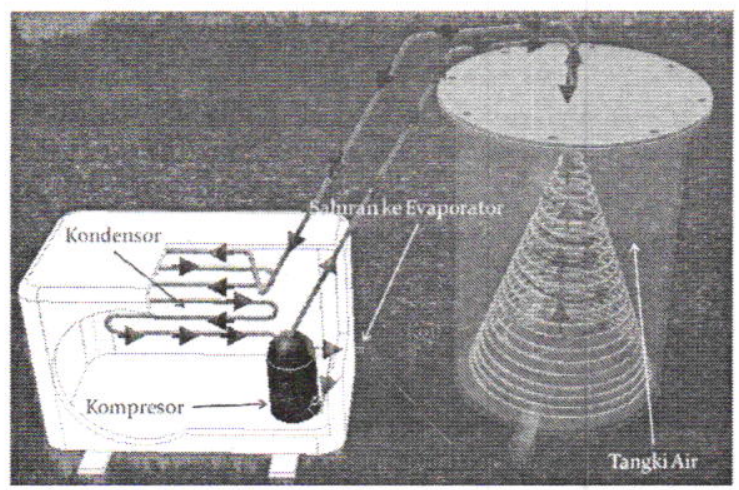

Gambar 3. disain sistem AWH

5. Pengujian AWH

6. Analisis Data

\section{HASIL DAN PEMBAHASAN \\ Data dari Literatur}

Pada penelitian yang dilakukan oleh peneliti sebelumnya yaitu pada tahun 2010, menggunakan pipa pemanas air tipe konus dengan dimensi yang ditentukan yaitu panjang (L) 15 meter dan diameter (D) sebesar 7,75 mm dapat menghasilkan air panas bertemperatur $60^{\circ} \mathrm{C}$ dicapai dalam waktu 130 menit. Sementara penurunan tekanan yang terjadi sampai mencapai $36 \mathrm{kPa}$.

Penurunan tekanan yang terjadi melebihi batas yang diijinkan untuk alat penukar panas yaitu lebih besar dari $34 \mathrm{kPa}$. Hal tersebut dapat menyebabkan terjadinya penurunan kinerja dari mesin AC karena dapat mengganggu atau 
mempengaruhi kerja dari kompresornya.

\section{Data Dimensi Pipa Pemanas Hasil Perhitungan}

Hasil perhitungan untuk memperoleh dimensi dari pipa pemanas air yang effektif menggunakan asumsi bahwa air yang akan dipanaskan mencapai temperatur $60^{\circ} \mathrm{C}$ diperoleh data sebagai berikut:

- Diameter pipa(D) $=7,75 \mathrm{~mm}$

- $\quad$ Panjang pipa (L) $=13,57$ meter

Selain itu berdasarkan perhitungan, didapat perkiraan waktu untuk memanaskan air sebanyak 100 liter dengan asumsi temperatur awal $23^{\circ} \mathrm{C}$ dan temperatur akhir $60^{\circ} \mathrm{C}$ adalah 2 jam 50 menit. Sedangkan besarnya penurunan tekanan yang terjadi dari hasil perhitungan adalah $28,41 \mathrm{kPa}$, sehingga dianggap tidak akan mengganggu kinerja dari mesin AC. Karena pressure drop $(\Delta \mathrm{P})<34 \mathrm{kPa}$.

\section{Data Hasil Pengujian}

Hasil pengujian Airconditioner Water Heater(AWH) menggunakan dimensi pipa pemanas air sesuai perhitungan yaitu panjang pipa (L) 13,57 meter dan diameter pipa (D) sesuai dengan diameter kondensor yaitu 7,75 $\mathrm{mm}$, diperoleh hasil sebagai berikut:

- Untuk memanaskan air dari temperatur $28^{\circ} \mathrm{C}$ sampai temperatur $60^{\circ} \mathrm{C}$ membutuhkan waktu 165 menit atau 2 jam 45 menit.

- Penurunan tekanan $(\Delta \mathrm{P})$ yang terjadi selama pengujian sebesar $24 \mathrm{kPa}$.

Dari data hasil pengujian diatas, jika dibandingkan dengan data hasil perhitungan maka terlihat ada sedikit perbedaan hasil, dimana lamanya waktu pemanasan air hasil pengujian relatif lebih cepat yaitu sekitar 5 menit dari data hasil perhitungan. Hal ini terjadi karena pada data perhitungan menggunakan asumsi bahwa temperatur awal air sebesar $23^{\circ} \mathrm{C}$, sedangkan pada saat pengujian temperatur awal air dimulai dari angka sekitar $28^{\circ} \mathrm{C}$.

Jika dibandingkan dengan data dari literatur atau pengujian sebelumnya ditahun 2010 , dengan panjang pipa 15 meter, maka waktu pemanasan air berdasarkan pengujian ditahun 2011 ini, memperoleh waktu yang relatif lebih lama, yaitu mempunyai selisih waktu sebanyak 35 menit. Lamanya waktu pemanasan air disebabkan karena panjang pipa (L) pemanas air lebih pendek dengan selisih 1,43 meter. Hal ini sesuai dengan teori perpindahan panas yang ditunjukkan pada persamaan (2). Yaitu besarnya energi perpindahan panas dipengaruhi oleh panjang pipa (L). Dan semakin besar L maka waktu pemanasan air yang dibutuhkan semakin lebih cepat.

Akan tetapi panjang pipa juga mempengaruhi terjadinya penurunan tekanan $(\Delta \mathrm{P})$. Hal ini sesuai teori yang ditunjukkan oleh persamaan (8). Dimana semakin besar L, maka penurunan tekanan $(\Delta \mathrm{P})$ yang terjadi akan semakin besar. Pada data pengujian dengan panjang pipa yang lebih pendek yaitu L sebesar 13,57 meter, jika dibandingkan dari pengujian sebelumnya diperoleh $\Delta$ P yang lebih rendah yaitu sebesar 24 $\mathrm{kPa}$. Hasil $\Delta \mathrm{P}$ ini cukup baik karena berada pada daerah aman atau daerah yang diijinkan untuk suatu alat perpindahan panas yaitu $\Delta \mathrm{P}<34 \mathrm{kPa}$. Sementara dari hasil literatur sebelumnya diperoleh $\triangle \mathrm{P}$ yang kurang baik karena berada pada daerah yang tidak aman $>34 \mathrm{kPa}$ yaitu sebesar $36 \mathrm{kPa}$.

\section{Analisis Data}

Salah satu parameter dari kinerja Airconditioner Water Heater (AWH) yaitu menghasilkan air panas dalam waktu yang relatif cepat, dan menghasilkan penurunan tekanan $(\Delta \mathrm{P})$ pada daerah yang aman atau $<34 \mathrm{kPa}$. Optimalisasi kinerja AWH dilakukan dengan mengatur dimensi pipa pemanas air yaitu panjang pipa (L). Pengaturan panjang pipa (L) menggunakan metode perhitungan berdasarkan prinsif-prinsif perpindahan panas dan dilakukan secara trial and error karena data awal perhitungan memakai data spesifikasi alat dan beberapa asumsi-asumsi. Untuk dapat mengetahui apakah pengaturan panjang pipa (L) dengan metode perhitungan tersebut menghasilkan kinerja yang baik atau tidak maka dilakukan pengujian alat. Hasil dari pengujian kemudian dibandingkan dengan data dari literatur dan data perhitungan.

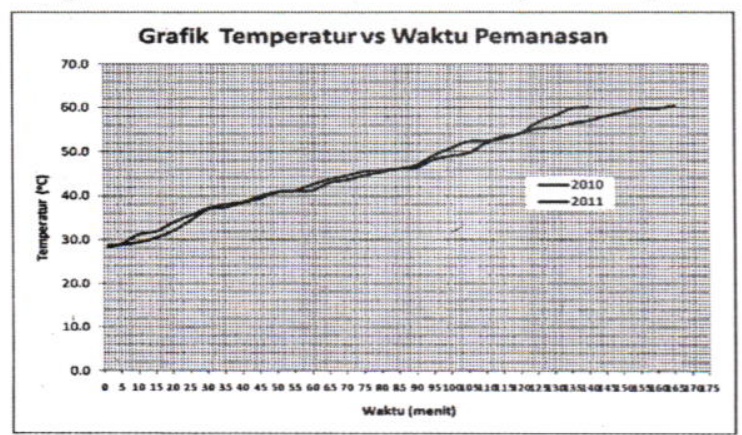

Gambar.4 Grafik T air vs Waktu Pemanasan 
Pada Gambar 4 yaitu grafik yang menunjukkan temperatur pemanasan air terhadap waktu, maka pengujian yang dilakukan sebelum dilakukan optimalisasi dan setelah dilakukan optimalisasi terlihat bahwa untuk mencapai temperatur pemanasan air sampai sebesar $50{ }^{\circ} \mathrm{C}$ memerlukan waktu yang hampir sama. Tetapi untuk mencapai temperatur pemanasan air sampai $60^{\circ} \mathrm{C}$, maka ada selisih waktu sebesar 35 menit.

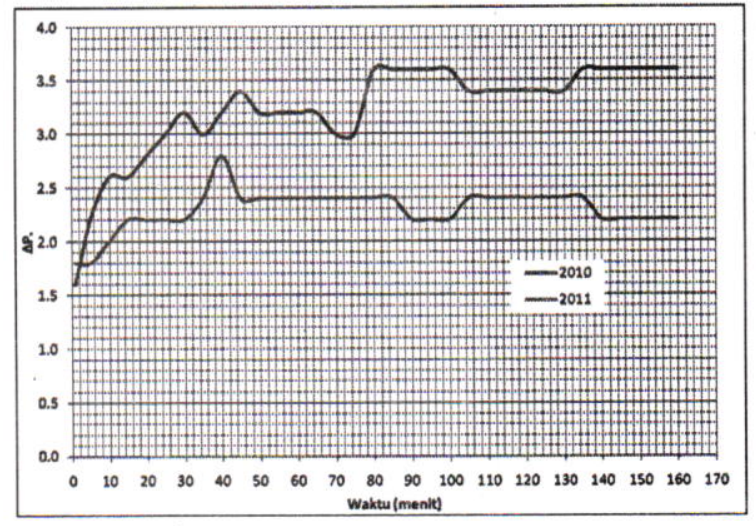

Gambar 5. Grafik $\Delta \mathrm{P}$ vs waktu

Sedangkan pada Gambar 5, yaitu grafik yang menggambarkan antara penurunan tekanan $(\Delta \mathrm{P})$ terhadap waktu pemanasan air maka terlihat bahwa penurunan tekanan sistem AWH pada pengujian setelah dilakukan optimalisasi relatif lebih stabil dan aman karena berada pada $22-24 \mathrm{kPa}$. Tetapi untuk pengujian yang dilakukan sebelumnya penurunan tekanan pada sistem terlihat berada pada daerah 30-36 $\mathrm{kPa}$. Hal ini menunjukkan bahwa pengujian sebelum dilakukan optimalisasi menghasilkan pressure drop pada daerah yang kurang aman.

\section{KESIMPULAN}

1. Hasil dari metode perhitungan diketahui panjang pipa (L) efektif untuk pemanas air sebesar 13,57 meter dengan menghasilkan pressure drop $(\Delta \mathrm{P})$ sebesar $28,41 \mathrm{kPa}$. Panjang pipa ini lebih pendek 1,43 meter dibandingkan dengan panjang pipa pada penelitian sebelumnya yaitu 15 meter dengan pressure drop $36 \mathrm{kPa}$.

2. Dari metode perhitungan untuk dapat memanaskan air dari temperatur lingkungan sampai tercapai temperatur $60{ }^{\circ} \mathrm{C}$ memerlukan waktu 2 jam 50 menit.
3. Dari hasil pengujian sistem AWH untuk memanaskan air dari temperatur lingkungan sampai tercapai temperatur $60{ }^{\circ} \mathrm{C}$ memerlukan waktu 2 jam 45 menit, dan menghasilkan pressure drop sebesar 24 $\mathrm{kPa}$.

4. Kinerja AWH akan optimal jika waktu untuk memanaskan air kurang dari 3 jam dengan menghasilkan pressure drop dibawah 34 $\mathrm{kPa}$.

\section{DAFTAR PUSATAKA}

Hewitt, G. F., Shires, G. L. Shires, dan Bott, T. R., Process Heat Transfer. Begell House, New York, 2000.

Incropera, F. P., Dewitt, D. P., Bergman, T. L., dan Lavine A. S., Introduction to Heat Transfer, Edisi 5E, John Willey \& Sons, New York, 2007.

Jie Ji, Domestic Air Conditioner and Integrated Water Heater for Subtropical Climate, Journal Applied Thermal Engineering, 23(2003) 581-592.2003.

Koestoer. R.A, Air Conditioning Water Heater (ACWH), Raldi Artono Koestoer.htm, 2008

Moran, M. J dan H. N. Shapiro, Fundamentals of Engineering Thermodynamics, Edisi 3, John Willey \& Sons, New York, 1996.

Ong, K. S., A Technical Note on Heating and Cooling Using the Vapour-Compression Refrigerating machine, Buletin Institution of Engineering Malaysia (IEM), 1995.

P. Techarungpaisan, Modeling of A Split Type Air Conditioner with Integrated Water Heater, Mechanical Engineering Department, Faculty of Engineering, Khon Kaen University, 123 Mittrapab Rd., Muang, Khon Kaen 40002, Thailand 2006.

Sinaga, J. B., Buku Kerja Audit Energi untuk Hotel dan Motel dan Pemanfaatan Energi yang Dikeluarkan dari Kondensor untuk Pemanasan Air, Tesis Pascasarjana, Teknik Mesin ITB, Bandung, 2000.

Tanuwijaya, A.O. Pemanfaatan Ganda Mesin Pendingin sebagai Pompa Kalor untuk Pemanasan Air Skala Rumah Tangga, Tugas Sarjana, Teknik Mesin ITB, Bandung, 2009. 